Acknowledgment. The investigation was supported in part (A.L.S.) by the Netherlands Foundation for Chemical Research (SON) with financial aid from the Netherlands Organization for Advancement of Pure Research (ZWO). The X-ray data were collected by Dr. A. J. M. Duisenberg. Professor K. Vrieze is thanked for helpful discussions.

Registry No. $4,114762-89-9 ; 4-d_{3}, 114762-95-7 ; 5,114762-90-2$ 6, 114762-91-3; 7, 114762-92-4; 7-d, $114762-96-8$; 8, 114762-93-5; 9, 114762-94-6; 2,6-( $\left.\mathrm{Me}_{2} \mathrm{NCH}_{2}\right)_{2} \mathrm{C}_{6} \mathrm{H}_{3} \mathrm{Br}, 66479-06-9 ;[\mathrm{IrCl}(\mathrm{COD})]_{2}$,
12112-67-3; 1-Me-2-Br-3- $\left(\mathrm{Me}_{2} \mathrm{NCH}_{2}\right) \mathrm{C}_{6} \mathrm{H}_{3}, 114739-32-1 ; \mathrm{Li}_{4}$ $\left[\mathrm{C}_{6} \mathrm{H}_{4}\left(\mathrm{CH}_{2} \mathrm{NMe}_{2}\right)-2\right]_{4}, 56174-66-4 ; 2-\mathrm{Br}-1,3,5-\left(\mathrm{Me}_{2} \mathrm{NCH}_{2}\right)_{3} \mathrm{C}_{6} \mathrm{H}_{2}$, 114739-29-6; 2-bromo-1,3-dimethylbenzene, 576-22-7; 2-bromo1,3-dimethylbenzene- $d_{3}, 114739-30-9 ; 2$-bromo-1,3-bis $((\mathrm{di}-$ methylamino)methyl) benzene- $d_{3}, 114739-31-0$.

Supplementary Material Available: Lists of hydrogen atom positions and thermal parameters and complete lists of bond distances and angles (4 pages); a listing of the $F_{0}$ and $F_{\mathrm{c}}$ values (25 pages). Ordering information is given on any current masthead page.

\title{
Formation of Octahedral Iridlum(III) Dihydrides from the Reaction of Ortho-Chelated Aryliridium(I) Compounds with Dihydrogen
}

\author{
Adolphus A. H. van der Zeljden, Gerard van Koten, " Ronald Luljk, and David M. Grove \\ Anorganisch Chemisch Laboratorium, University of Amsterdam, Nieuwe Achtergracht 166, \\ 1018 WV Amsterdam, The Netherlands
}

Received November 6, 1987

\begin{abstract}
The reaction of $\operatorname{Ir}^{\mathrm{I}}\left[\mathrm{C}_{6} \mathrm{H}_{2}\left(\mathrm{CH}_{2} \mathrm{NMe}_{2}\right)-2-\mathrm{R}^{1}-4-\mathrm{R}^{2}-6\right](\mathrm{COD})(\mathrm{COD}=$ cycloocta-1,5-diene) with dihydrogen in $\mathrm{CD}_{2} \mathrm{Cl}_{2}$ was monitored by ${ }^{1} \mathrm{H}$ NMR. At $-20^{\circ} \mathrm{C}$ quantitative formation of the novel dihydride complexes $\left.\mathrm{Ir}^{\mathrm{III}} \mathrm{H}_{2} \mathrm{C}_{6} \mathrm{H}_{2}\left(\mathrm{CH}_{2} \mathrm{NMe}_{2}\right)-2-\mathrm{R}^{1}-4-\mathrm{R}^{2}-6\right]$ (COD) $\left[\mathrm{R}^{1}=\mathrm{H}, \mathrm{R}^{2}=\mathrm{CH}_{2} \mathrm{NMe}_{2}(10), \mathrm{Me}(11) ; \mathrm{R}^{2}=\mathrm{H}, \mathrm{R}^{1}=\mathrm{H}(12)\right.$, $\mathrm{Me}(13), \mathrm{CH}_{2} \mathrm{NMe}_{2}$ (14); $\mathrm{R}^{1}=\mathrm{R}^{2}=\mathrm{CH}_{2} \mathrm{NMe}_{2}$ (15)] occurs. Further reactions, the type of which depends on the bulkiness of the $\mathrm{R}^{1}$ and $\mathrm{R}^{2}$ groups, occur when these solutions are warmed to $0^{\circ} \mathrm{C}$. Complexes 12-14 $\left(\mathrm{R}^{2}=\mathrm{H}\right)$ lose $\mathrm{H}_{2}$ to re-form $\operatorname{Ir}^{\mathrm{I}}\left[\mathrm{C}_{6} \mathrm{H}_{3}\left(\mathrm{CH}_{2} \mathrm{NMe}_{2}\right)-2-\mathrm{R}^{1}-4\right](\mathrm{COD})$. In contrast, complexes 10, 11, and $15\left(\mathrm{R}^{2}\right.$ $=$ alkyl) react further by means of $\mathrm{C}\left(\right.$ aryl)-H reductive elimination. For complex $15\left(\mathrm{R}^{1}=\mathrm{CH}_{2} \mathrm{NMe}_{2}\right)$ this results in quantitative formation of 1,3,5-( $\left(\mathrm{Me}_{2} \mathrm{NCH}_{2}\right)_{3} \mathrm{C}_{6} \mathrm{H}_{3}$ and "IrH(COD)". In $\operatorname{Ir}{ }^{11 I} \mathrm{H}_{2}\left[\mathrm{C}_{6} \mathrm{H}_{3}\right.$ $\left.\left(\mathrm{CH}_{2} \mathrm{NMe}_{2}\right)-2-\mathrm{R}-6\right](\mathrm{COD})[\mathrm{R}=$ alkyl $(\mathbf{1 0}$ and 11$)], \mathrm{C}$ (aryl)- $\mathrm{H}$ reductive elimination is followed by re-addition of another $\mathrm{C}$ (aryl) $\mathrm{H}$ bond, which upon subsequent reductive elimination of $\mathrm{H}_{2}$, yields the rearranged iridium(I) complexes $\operatorname{Ir}^{\mathrm{I}}\left[\mathrm{C}_{6} \mathrm{H}_{3}\left(\mathrm{CH}_{2} \mathrm{NMe}_{2}\right)-2-\mathrm{R}-4\right]$ (COD). Since the rearrangement of $\operatorname{Ir}^{\mathrm{I}}\left[\mathrm{C}_{6} \mathrm{H}_{3}\right.$ $\left.\left(\mathrm{CH}_{2} \mathrm{NMe}_{2}\right)-2-\mathrm{R}-6\right](\mathrm{COD})$ to $\operatorname{Ir}^{\mathrm{I}}\left[\mathrm{C}_{6} \mathrm{H}_{3}\left(\mathrm{CH}_{2} \mathrm{NMe}_{2}\right)-2-\mathrm{R}-4\right](\mathrm{COD})$ can also be induced thermally at $60^{\circ} \mathrm{C}$, it is therefore being catalyzed by dihydrogen at $0^{\circ} \mathrm{C}$. None of these reactions with dihydrogen is attended by hydrogenation of the COD ligand.
\end{abstract}

\section{Introduction}

The oxidative addition of dihydrogen to metal $\mathrm{d}^{8} \mathrm{com}$ plexes is a key step in homogeneous hydrogenation and hydroformylation catalysis. ${ }^{1}$ Since the discovery of the first stable metal dihydrido olefin complexes in 1976 by Crabtree et al., ${ }^{2}$ several papers have emerged on the observation of other species of this type. ${ }^{3}$ These species, as well as recently isolated cis-alkyl/aryl/acyl hydride rhodium and iridium complexes, ${ }^{4}$ can be regarded as intermediates in the homogeneous catalytic hydrogenation of olefins.

In previous papers we reported the syntheses of $\mathrm{M}^{\mathrm{I}}$ $\left[\mathrm{C}_{6} \mathrm{H}_{3}\left(\mathrm{CH}_{2} \mathrm{NMe}_{2}\right)-2-\mathrm{R}-6\right]$ (COD) [ $\mathrm{M}=\mathrm{Rh}, \mathrm{R}=\mathrm{CH}_{2} \mathrm{NMe}_{2}$ (1), $\mathrm{Me} \mathrm{(2),} \mathrm{H}(3) ;{ }^{5} \mathrm{M}=\mathrm{Ir}, \mathrm{R}=\mathrm{CH}_{2} \mathrm{NMe}_{2}$ (4), $\mathrm{Me}$ (5), $\mathrm{H}$ (6)] and $\operatorname{Ir}^{1}\left[\mathrm{C}_{6} \mathrm{H}_{2}\left(\mathrm{CH}_{2} \mathrm{NMe}_{2}\right)_{3}-2,4,6\right]$ (COD) (9); 1. We also reported that compounds 4 and 5 , which suffer from internal steric crowding between the 6-substituted alkyl group and the adjacent COD double bond, isomerize quantitatively in an unusual way to $\operatorname{Ir}^{1}\left[\mathrm{C}_{6} \mathrm{H}_{3}\right.$. $\left.\left(\mathrm{CH}_{2} \mathrm{NMe}_{2}\right)-2-\mathrm{R}-4\right](\mathrm{COD})\left[\mathrm{R}=\mathrm{CH}_{2} \mathrm{NMe}_{2}(7)\right.$ and $\mathrm{Me}(8)$, respectively]. The mechanism of this conversion involves

* To whom correspondence should be addressed at the Laboratory of Organic Chemistry, University of Utrecht, Department of Metal Mediated Synthesis, Padualaan 8, $3584 \mathrm{CH}$ Utrecht, The Netherlands. the successive intramolecular breaking and making of several C-H bonds (see Scheme I). Some of the postulated intermediates in this conversion involve iridium(III) hydride species yet, despite the cis arrangement of the metal hydride and one of the double bonds of COD, no hydrogenation of COD was observed. In view of this it was anticipated that the reaction of molecular hydrogen with the iridium(I) complexes 4-9 might lead to isolable iridium(III) dihydride species. This paper contains the results

(1) Dickson, R. S. Homogeneous Catalysis with Compounds of Rhodium and Iridium; D. Reidel: Dordrecht, Holland, 1985.

(2) Crabtree, R. H. Acc. Chem. Res. 1979, $12,331$.

(3) (a) Crabtree, R. H.; Felkin, H.; Fillebeen-Khan, T.; Morris, G. E. J. Organomet. Chem. 1979, 168, 183. (b) Crabtree, R. H.; Uriarte, R. J. Inorg. Chem. 1983, 22, 4152. (c) Burk, M. J.; Crabtree, R. H.; Holt, E. M. Organometallics, 1984, 3, 638. (d) Fernandez, M. J.; Esteruelas, M. A.; Jimenez, M. S.; Oro, L. A. Organometallics 1986, 5, 1519. (e) Kretschmer, M.; Pregosin, P. S.; Albinati, A.; Togni, A. J. Organomet. Chem. 1985, 281, 365 .

(4) (a) Milstein, D. Acc. Chem. Res. 1984, 17, 221. (b) Arpac, E.; Mirzaei, F.; Yardimcioglu, A.; Dahlenburg, L. Z. Anorg. Allg. Chem. 1984, 519, 148. (c) Thorn, D. L. Organometallics 1986, 5, 1897. (d) Bennett, M. A.; Crisp, G. T. Organometallics 1986, 5, 1792. (e) Bennett, M. A.; Crisp, G. T. Organometallics 1986, 5, 1800. (f) Bianchini, C.; Peruzzini, M.; Zanobini, J. J. Organomet. Chem. 1987, 326, C79. (g) Fryzuk, M. D.; MacNeil, P. A.; Rettig, S. J. J. Am. Chem. Soc. 1987, 109, 2803.

(5) van der Zeijden, A. A. H.; van Koten, G.; Nordemann, R. A.; Kojič Prodič, B.; Spek, A. L. Organometallics, in press.

(6) van der Zeijden, A. A. H.; van Koten, G.; Luijk, R.; Nordemann, R. A.; Spek, A. L. Organometallics, preceding paper in this issue. 

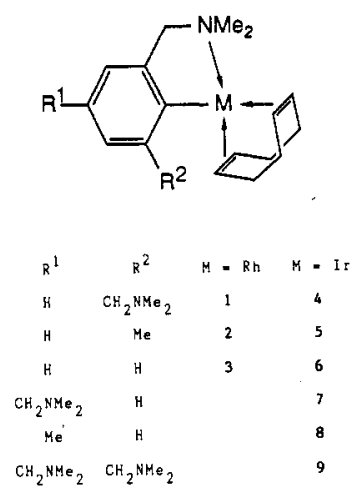

Figure 1. Solid-state structures of $\mathrm{M}^{\mathrm{I}}\left[\mathrm{C}_{6} \mathrm{H}_{2}\left(\mathrm{CH}_{2} \mathrm{NMe}_{2}\right)-2-\mathrm{R}^{1}-4\right.$ $\left.\mathrm{R}^{2}-6\right](\mathrm{COD})$ (1-9).

of these investigations that have led to the identification of dihydride complexes that also bear olefin and aryl functions around the iridium center.

\section{Experimental Section}

General Data. All manipulations were conducted under an atmosphere of dry nitrogen. The compounds $\operatorname{Ir}\left[\mathrm{C}_{6} \mathrm{H}_{3^{-}}\right.$ $\left.\left(\mathrm{CH}_{2} \mathrm{NMe}_{2}\right)_{2}-2,6\right](\mathrm{COD})(4), \operatorname{Ir}\left[\mathrm{C}_{6} \mathrm{H}_{3}\left(\mathrm{CH}_{2} \mathrm{NMe}_{2}\right)\right.$-2-Me-6](COD) (5), $\mathrm{Ir}\left[\mathrm{C}_{6} \mathrm{H}_{4}\left(\mathrm{CH}_{2} \mathrm{NMe}_{2}\right)-2\right](\mathrm{COD})(6), \mathrm{Ir}\left[\mathrm{C}_{6} \mathrm{H}_{3}\left(\mathrm{CH}_{2} \mathrm{NMe}_{2}\right)_{2}-2,4\right]-$ (COD) (7), $\operatorname{Ir}\left[\mathrm{C}_{6} \mathrm{H}_{3}\left(\mathrm{CH}_{2} \mathrm{NMe}_{2}\right)-2-\mathrm{Me}-4\right](\mathrm{COD})(8)$, and $\operatorname{Ir}\left[\mathrm{C}_{6} \mathrm{H}_{2-}\right.$ $\left.\left(\mathrm{CH}_{2} \mathrm{NMe}_{2}\right)_{3}-2,4,6\right]$ (COD) (9) were synthesized according to ref 6.

Reaction of the Iridium(I) Complexes (4-9) with $\mathrm{H}_{2}$. Formation of Dihydride Species and NMR Measurements. In a typical experiment a red solution of ca. $0.15 \mathrm{mmol}$ of one of the iridium complexes, $4-9$, in $1.5 \mathrm{~mL}$ of dry $\mathrm{CD}_{2} \mathrm{Cl}_{2}$ was cooled to $-20( \pm 5)^{\circ} \mathrm{C}$. When hydrogen was bubbled through this solution for ca. $1 \mathrm{~min}$, a clear yellow solution resulted. At this temperature, $0.5 \mathrm{~mL}$ of the reaction mixture, containing the iridium(III) dihydride complex, was transferred to a precooled 5-mm NMR tube. Subsequent ${ }^{1} \mathrm{H}$ NMR spectra were recorded first at $-20^{\circ} \mathrm{C}$ and then with increasing temperature at intervals of $10^{\circ}$ up to +20 ${ }^{\circ} \mathrm{C}$ on a Bruker WM250 spectrometer.

\section{Results and Discussion}

Formation and Characterization of $\mathrm{Ir}^{\mathrm{II}} \mathrm{H}_{2}\left[\mathrm{C}_{6} \mathrm{H}_{2^{-}}\right.$ $\left.\left(\mathrm{CH}_{2} \mathrm{NMe}_{2}\right)-2-\mathrm{R}^{1}-4-\mathrm{R}^{2}-6\right]$ (COD) (10-15). The orange-red complexes $\operatorname{Ir}^{\mathrm{I}}\left[\mathrm{C}_{6} \mathrm{H}_{2}\left(\mathrm{CH}_{2} \mathrm{NMe}_{2}\right)-2-\mathrm{R}^{1}-4-\mathrm{R}^{2}-6\right](\mathrm{COD})$ (4-9) have square-planar configurations in the solid state, with a $\mathrm{C}, \mathrm{N}$-coordinated aryl ligand and a bidentate COD ligand (Figure 1). ${ }^{6}$ Bubbling dihydrogen through solutions of these complexes in $\mathrm{CD}_{2} \mathrm{Cl}_{2}$ at $-20( \pm 5){ }^{\circ} \mathrm{C}$ results in rapid formation of a yellow solution containing the iridium(III) dihydride species $\mathrm{Ir}^{\mathrm{III}} \mathrm{H}_{2}\left[\mathrm{C}_{6} \mathrm{H}_{2}\left(\mathrm{CH}_{2} \mathrm{NMe}_{2}\right)-2-\mathrm{R}^{1}-4-\mathrm{R}^{2}-6\right]$ (COD) (10-15) (Figure 2). The oxidative addition reaction proceeded very cleanly in this narrow temperature range, and ${ }^{1} \mathrm{H}$ NMR measurements at $-20^{\circ} \mathrm{C}$ of these clear solutions showed the iridium(III) dihydrides to be the only
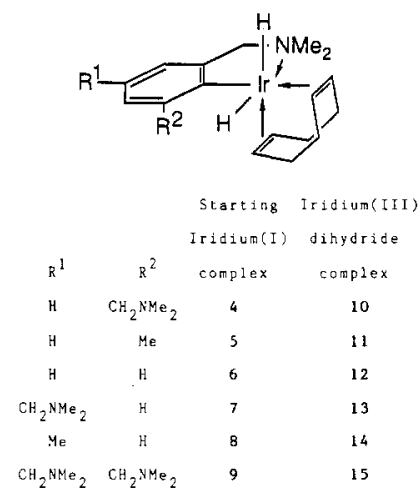

Figure 2. Structures of $\operatorname{Ir}^{\mathrm{III}} \mathrm{H}_{2}\left[\mathrm{C}_{6} \mathrm{H}_{2}\left(\mathrm{CH}_{2} \mathrm{NMe}_{2}\right)-2-\mathrm{R}^{1}-4-\mathrm{R}^{2}-6\right]$ (COD) $(10-15)$ in solution at $-20^{\circ} \mathrm{C}$.
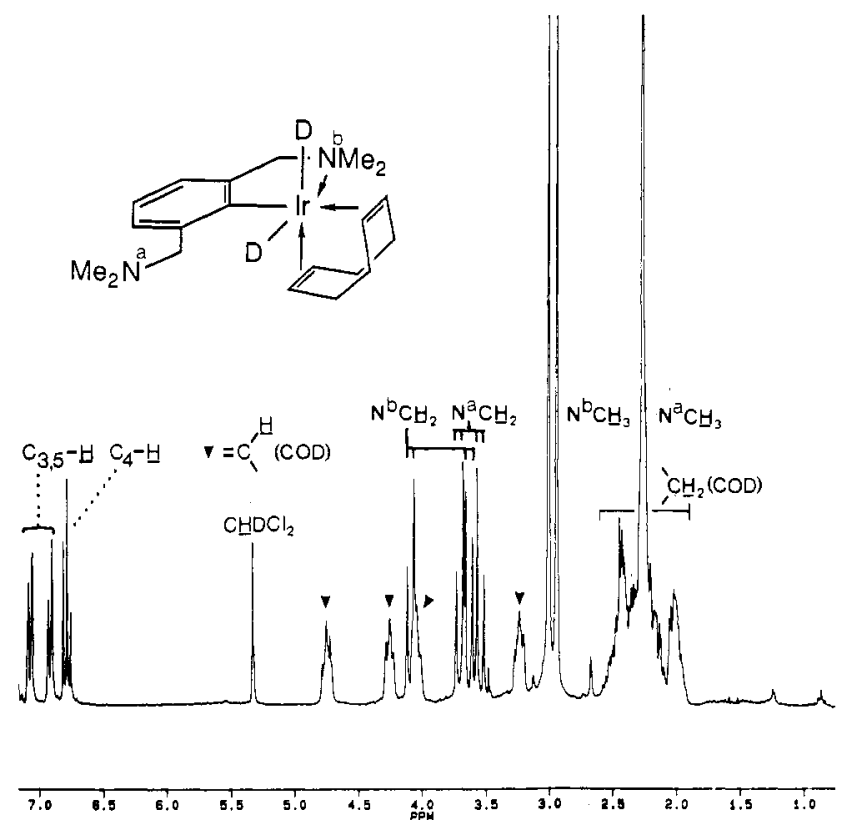

Figure 3. ${ }^{1} \mathrm{H}$ NMR spectrum of $\mathrm{Ir}^{\mathrm{III}} \mathrm{D}_{2} \mathrm{CC}_{6} \mathrm{H}_{3}\left(\mathrm{CH}_{2} \mathrm{NMe}_{2}\right)_{2}$ $2,6](\mathrm{COD})\left(10-d_{2}\right)$ in $\mathrm{CD}_{2} \mathrm{Cl}_{2}$ at $-20^{\circ} \mathrm{C}$.

species present. As complexes 10-15 were found to be unstable above $0^{\circ} \mathrm{C}$ in solution, identification was restricted to in situ ${ }^{1} \mathrm{H}$ NMR spectroscopy and no attempts were made to isolate solid products.

The iridium(III) dihydride complexes 10-15 can be readily characterized by their distinctive ${ }^{1} \mathrm{H}$ NMR spectra (Table I and Figure 3). There are two hydride resonances with equal intensity at ca. -9 and $-17 \mathrm{ppm}$, which are singlets within the resolution of the NMR measurements $(0.5 \mathrm{~Hz})$. The four olefinic protons of COD appear as four separate signals, indicative of the complete absence of

Scheme I. Postulated Mechanism for the Conversion of $\operatorname{Ir}^{\mathrm{I}}\left[\mathrm{C}_{6} \mathrm{H}_{3}\left(\mathrm{CH}_{2} \mathrm{NMe}_{2}\right)-2-\mathrm{R}-6\right](\mathrm{COD})\left[R=\mathrm{CH}_{2} \mathrm{NMe}_{2}(4)\right.$, $\left.\mathrm{Me}^{(5)}\right]$ to $\mathrm{Ir}^{\mathrm{I}}\left[\mathrm{C}_{6} \mathrm{H}_{3}\left(\mathrm{CH}_{2} \mathrm{NMe}_{2}\right)-2-\mathrm{R}-4\right](\mathrm{COD})\left[\mathrm{R}=\mathrm{CH}_{2} \mathrm{NMe}_{2}(7), \mathrm{Me}(8)\right]^{6}$

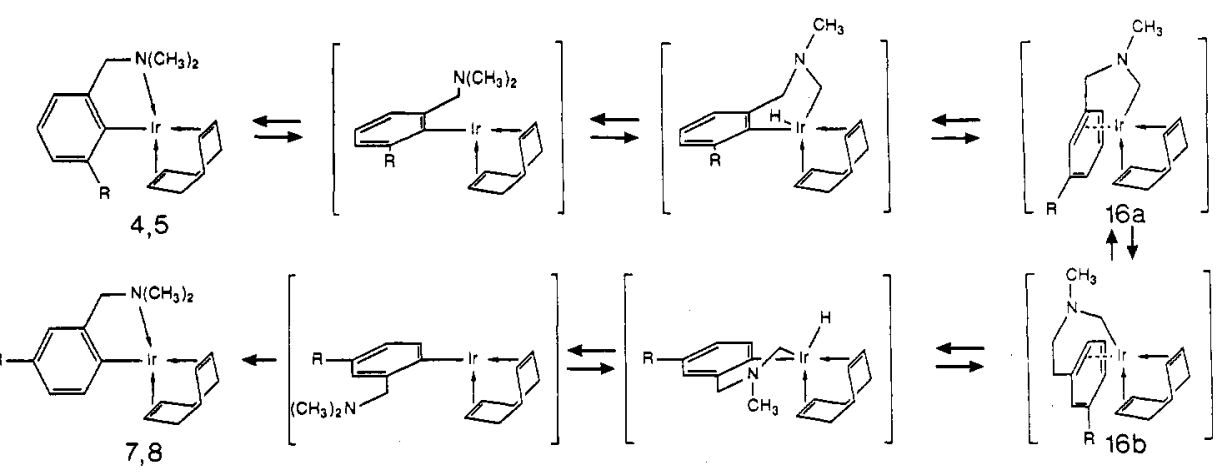


Table I. ${ }^{1} \mathrm{H}$ NMR Data of $\mathrm{IrH}_{2}\left[\mathrm{C}_{6} \mathrm{H}_{2}\left(\mathrm{CH}_{2} \mathrm{NMe}_{2}\right)-2-\mathrm{R}^{1}-4-\mathrm{R}^{2}-6\right](\mathrm{COD})^{a}$

\begin{tabular}{|c|c|c|c|c|c|c|c|}
\hline \multirow[b]{2}{*}{ compd } & \multirow[b]{2}{*}{$\mathrm{R}^{1}$} & \multirow[b]{2}{*}{$\mathbf{R}^{2}$} & \multicolumn{2}{|c|}{ 2- $\mathrm{CH}_{2} \mathrm{NMe}_{2}$ group } & \multirow{2}{*}{$\begin{array}{c}\text { other aromatic protons and } \\
\text { substituents }\end{array}$} & \multirow[b]{2}{*}{$=\mathrm{CH}(\mathrm{COD})^{\mathrm{c}}$} & \multirow[b]{2}{*}{$\operatorname{Ir} H$} \\
\hline & & & $\mathrm{CH}_{2}$ & $\mathrm{~N}\left(\mathrm{CH}_{3}\right)_{2}$ & & & \\
\hline 10 & $\mathrm{H}$ & $\mathrm{CH}_{2} \mathrm{NMe}_{2}$ & $3.63(\mathrm{~d}), 4.08$ (d) & $2.94(\mathrm{~s}), 3.00(\mathrm{~s})$ & $\begin{array}{l}H_{3,5}, 6.91(\mathrm{~d}), 7.07(\mathrm{~d}) ; H_{4}, 6.78 \\
\quad(\mathrm{t}) ; \mathrm{R}^{2}, \mathrm{CH}, 3.53(\mathrm{~d}), 3.70(\mathrm{~d}) \\
\quad \mathrm{CH}_{3}, 2.26(\mathrm{~s})\end{array}$ & $3.25,4.03,4.25,4.74$ & $-9.37,-16.41$ \\
\hline 11 & $\mathrm{H}$ & $\mathrm{Me}$ & $3.63(\mathrm{~d}), 4.10(\mathrm{~d})$ & $2.97(\mathrm{~s}), 3.01(\mathrm{~s})$ & $\begin{array}{l}\mathrm{H}_{3,5}, 6.89(\mathrm{~d}), 6.86(\mathrm{~d}) ; H_{4} ; 6.70 \\
\quad(\mathrm{t}) ; \mathrm{R}^{2}, \mathrm{CH}_{3}, 2.50(\mathrm{~s})\end{array}$ & $3.23,4.07,4.21,4.77$ & $-9.12,-16.44$ \\
\hline 12 & $\mathrm{H}$ & $\mathrm{H}$ & $3.68(\mathrm{~d}), 3.84(\mathrm{~d})$ & $2.68(\mathrm{~s}), 3.12(\mathrm{~s})$ & $\begin{array}{l}H_{3}, 6.99(\mathrm{~d}) ; H_{4,5}, 6.75(\mathrm{t}), 6.81 \\
\quad(\mathrm{t}) ; H_{6}, 7.49(\mathrm{~d})\end{array}$ & $2.83,4.09,4.61,4.74$ & $-9.16,-17.88$ \\
\hline 13 & $\mathrm{CH}_{2} \mathrm{NMe}_{2}$ & $\mathrm{H}$ & $3.66(\mathrm{~d}), 3.83(\mathrm{~d})$ & $2.67(\mathrm{~s}), 3.11(\mathrm{~s})$ & $\begin{array}{l}H_{3}, 6.94(\mathrm{~s}) ; H_{5}, 6.71(\mathrm{~d}) ; H_{6}, 7.40 \\
\quad(\mathrm{~d}) ; \mathrm{R}^{1}, \mathrm{C} H_{2}, 3.19(\mathrm{~s}), \mathrm{CH}_{3}, 2.11 \\
\quad(\mathrm{~s})\end{array}$ & $2.82,4.08,4.61,4.72$ & $-9.17,-17.91$ \\
\hline 14 & $\mathrm{Me}$ & $\mathrm{H}$ & $3.65(\mathrm{~d}), 3.83(\mathrm{~d})$ & $2.66(\mathrm{~s}), 3.13(\mathrm{~s})$ & $\begin{array}{l}H_{3}, 6.87(\mathrm{~s}) ; H_{5}, 6.69(\mathrm{~d}) ; H_{6}, 7.38 \\
\quad(\mathrm{~d}) ; \mathrm{R}^{1}, \mathrm{CH}_{3}, 2.51(\mathrm{~s})\end{array}$ & $2.83,4.09,4.62,4.75$ & $-9.13,-17.86$ \\
\hline 15 & $\mathrm{CH}_{2} \mathrm{NMe}_{2}$ & $\mathrm{CH}_{2} \mathrm{NMe}_{2}$ & $3.62(\mathrm{~d}), 4.04(\mathrm{~d})$ & $2.94(\mathrm{~s}), 2.96(\mathrm{~s})$ & $\begin{array}{l}H_{3,5}, 6.97(\mathrm{~s}), 6.84(\mathrm{~s}) ; \mathrm{R}^{1}, \mathrm{CH}_{2} \\
\quad 3.20(\mathrm{~s}) ; \mathrm{CH}_{3}, 2.11(\mathrm{~s}) ; \mathrm{R}^{2}, \mathrm{CH}_{2} \\
\quad 3.53(\mathrm{~d}), 3.70(\mathrm{~d}), \mathrm{CH}_{3}, 2.11(\mathrm{~s})\end{array}$ & $3.23,4.03,4.25,4.74$ & $-9.43,-16.47$ \\
\hline
\end{tabular}

${ }^{a}$ Measured in $\mathrm{CD}_{2} \mathrm{Cl}_{2}$ at $-20^{\circ} \mathrm{C}$ and $250 \mathrm{MHz}$. Chemical shifts $(\delta)$ relative to external TMS. ${ }^{b}$ For adjacent aryl protons, ${ }^{3} J(\mathrm{H}-\mathrm{H})=7 \mathrm{~Hz}$; for $\mathrm{CH}_{2} \mathrm{AB}$ doublets, ${ }^{2} J(\mathrm{H}-\mathrm{H})=13 \mathrm{~Hz}$. ${ }^{c}$ Broad resonance.

symmetry in these complexes. Finally, there is a single aryl ligand, which for all these complexes shows diastereotopic $\mathrm{CH}_{2}$ protons and $\mathrm{NMe}_{2}$ methyls in (one of) the $\mathrm{CH}_{2} \mathrm{NMe}_{2}$ group(s). This chirality of the $\mathrm{N}$ atom can only arise if this $\mathrm{CH}_{2} \mathrm{NMe}_{2}$ group is coordinated to the iridium center, and therefore the aryl ligand in complexes $10-15$ is always bidentate $\mathrm{C}, \mathrm{N}$-coordinated. Together with the two hydrides and the two coordinated double bonds of COD, this adds up to a six-coordinate iridium(III) complex, which almost certainly has a monomeric octahedral structure. Since the ${ }^{1} \mathrm{H}$ NMR data of the hydrides and olefinic protons of COD in 10-15 are all fairly similar, these complexes are believed to be isostructural.

A symmetrical structure in which the hydride atoms are in trans positions can be ruled out immediately on the basis of the above NMR data. There remain two other possible octahedral structures for these iridium(III) dihydrides in which the two hydrides are both in cis positions (isomers $\mathrm{a}$ and $\mathrm{b}$ in Scheme II). Despite the fact that the hydride atoms must be cis positioned, no mutual coupling was observed, but such couplings are usually very small $(<2 \mathrm{~Hz})^{3,7-9}$ Spectroscopically, the two postulated structures $a$ and $b$ can be discriminated on the basis of the ${ }^{1} \mathrm{H}$ chemical shifts of the hydride atoms. It is known that the chemical shifts of iridium hydride resonances keep a reliable track of the electronegativity of the opposing trans group. ${ }^{10}$ Thus, the ${ }^{1} \mathrm{H}$ NMR resonances of trans-C (either double bond or aryl/alkyl) hydrides are expected at ca. -11 $( \pm 2) \mathrm{ppm}$ and those of trans-N hydrides at ca. $-18( \pm 2)$ ppm. Accordingly, the hydride that appears at $-17 \mathrm{ppm}$ in complexes $10-15$ should be trans to a nitrogen atom, which means that these complexes have structures designated as isomer a in Scheme II. Additionally, other facts point to a as being the most likely structure: (i) if complexes 10, 11, and 15 had structure b, there would be severe steric hindrance between the 6-substituted $R^{2}$ group and the trans-N olefinic group of COD; (ii) the resonances of one of the hydrides appear in the extremely narrow range of $-16.44( \pm 0.03)$ ppm for the three complexes 10,11 , and 15 and of $-17.89( \pm 0.03) \mathrm{ppm}$ for the other three complexes 12-14. This clear difference can only be readily explained by the influence of the adjacent $R^{2}$ group in structure $a$, which is a proton in complexes 12-14 and an alkyl group

(7) Fisher, B. J.; Eisenberg, R. Organometallics 1983, $2,764$.

(8) Johnson, C. E.; Eisenberg, R. J. Am. Chem. Soc. 1985, 107, 3148.

(9) Yang, C.; Socol, S. M.; Kountz, D. J.; Meek, D. W.; Glaser, R. Inorg. Chim. Acta 1986, 114, 119.

(10) Olgemoeller, B.; Beck, W. Inorg. Chem. 1983, 22, 997.
Scheme 1I. Possible Pathways for the Cis Addition of Dihydrogen to $\mathrm{Ir}^{1}\left[\mathrm{C}_{6} \mathrm{H}_{2}\left(\mathrm{CH}_{2} \mathrm{NMe}_{2}\right)-2-\mathrm{R}^{1-4}-\mathrm{R}^{2}-6\right](\mathrm{COD})(4-9)$ Leading to the Formation of
$\mathrm{Ir}^{\mathrm{III}} \mathrm{H}_{2}\left[\mathrm{C}_{6} \mathrm{H}_{2}\left(\mathrm{CH}_{2} \mathrm{NMe}_{2}\right)-2-\mathrm{R}^{1}-4-\mathrm{R}^{2}-6\right](\mathrm{COD})(10-15)$

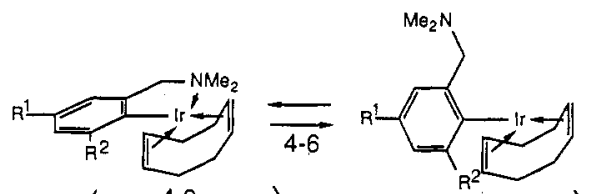

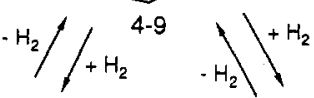

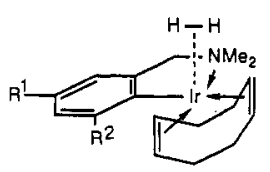
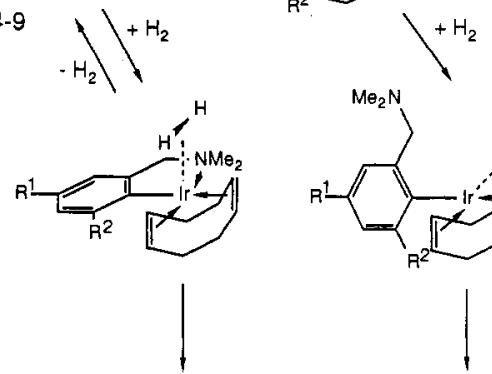

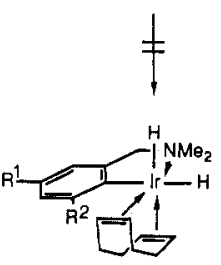

isomer b

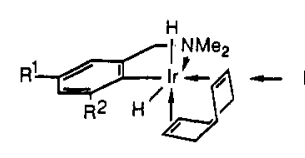

isomer a $(10-15)$ in complexes 10,11 , and 15 . Such behavior would not expected for the trans-C(aryl) hydride of structure $b$ because here it has the same spatial environment in all six iridium(III) complexes, 10-15. Evidently, the introduction of a 6-position alkyl group into the iridium(III) dihydride complexes 10,11 , and 15 causes a deshielding of the trans- $N$ hydride atom and a consequent downfield shift of $1.45 \mathrm{ppm}$. Finally, it is worth noting that in accordance with structure $a$, the other hydride (which is trans to a double bond of COD) resides in a position that is far away from the $R^{2}$ group, which explains why its ${ }^{1} \mathrm{H}$ chemical shift of $-9.28( \pm 0.15)$ ppm does not differ much within the six iridium(III) dihydrides.

Complexes 10-15 are rare examples of iridium(III) species having olefin, aryl, and hydride functions together around the same metal center. To our knowledge, the only other complex having this feature is dinuclear $\mathrm{PhH}$ (COD) $\operatorname{Ir}\left(\mu-\mathrm{C}_{12} \mathrm{H}_{8}\right) \operatorname{Ir}(\mathrm{COD}){ }^{11}$ It is further noted that the new hydrides $10-15$ are structurally related to the cationic

(11) Mueller, J.; Haensch, C.; Pickardt, J. J. Organomet. Chem. 1983, $259, \mathrm{C} 21$ 


\section{Scheme III. Thermally Induced Reactions of $\mathrm{Ir}^{\mathrm{II}} \mathrm{H}_{2}\left[\mathrm{C}_{6} \mathrm{H}_{2}\left(\mathrm{CH}_{2} \mathrm{NMe}_{2}\right)-2-\mathrm{R}^{1}-4-\mathrm{R}^{2}-6\right](\mathrm{COD})$ (10-15) upon Warming in Solution} from -20 to $0{ }^{\circ} \mathrm{C}$

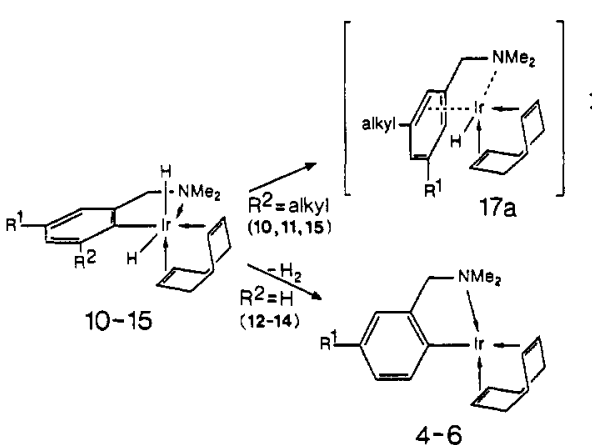

4-6

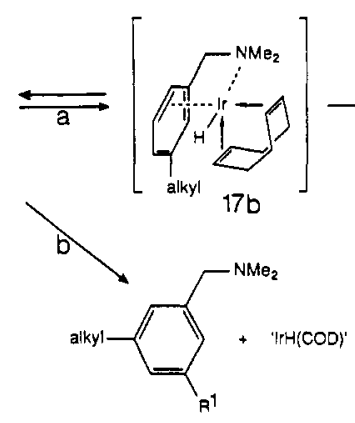

Route

$R^{1}=H(10,11)$

10 in the presence of $2 \mathrm{PPh}_{3} \quad 0 \% \quad 100 \%$

$\mathrm{R}^{1}=\mathrm{a} \mathrm{ky} \mathrm{l}=\mathrm{CH}_{2} \mathrm{NMe}_{2}$ (15) $0 \% \quad 200 \%$ complexes $\left[\mathrm{IrH}_{2}(\mathrm{COD}) \mathrm{L}_{2}\right]^{+}$, which currently are the most active catalysts known for the homogeneous hydrogenation of olefins. ${ }^{2}$

Mechanism of Dihydrogen Addition to $\operatorname{Ir}^{\mathrm{I}}\left[\mathrm{C}_{6} \mathrm{H}_{2^{-}}\right.$ $\left.\left(\mathrm{CH}_{2} \mathrm{NMe}_{2}\right)-2-\mathrm{R}^{1}-4-\mathrm{R}^{2}-6\right]$ (COD) (4-9). Knowing the geometry of the new iridium(III) dihydrides 10-15, it is now possible to discuss the available pathways for their formation from the iridium(I) precursors 4-9 (summarized in Scheme II). As mentioned earlier, the iridium(I) complexes 4 and 5, as well as 9 , suffer from steric crowding of the 6-position aryl $\mathrm{R}^{2}$ group and an adjacent double bond of COD. In solution these complexes relieve their strain by a reversible dissociation of the $\mathrm{Ir}-\mathrm{N}$ bond, followed by rotation of the aryl ligand out of the coordination plane, thereby creating a T-shaped 14-electron intermediate (see Scheme I, upper left, or Scheme II, upper part). It has been shown that this intermediate is the actual species that reacts intramolecularly with an $\mathrm{NMe} \mathrm{C}-\mathrm{H}$ bond to initiate the unique irreversible rearrangement depicted in Scheme I. ${ }^{6}$ However, irrespective of this fluxionality, compounds 4,5 , and 9 as well as the nonfluxional compounds $6-8$ react with dihydrogen to afford the isostructural cis-dihydride species 10-15. This means that attack of dihydrogen on the T-shaped three-coordinate species as well as on the square-planar four-coordinate species yields the same type of product.

A concerted cis addition of $\mathrm{H}_{2}$ to the square-planar arrangement of the iridium(I) complexes 4-9 can take place along either the $\mathrm{N}$-Ir-olefin or the $\mathrm{C}$ (aryl)-Ir-olefin' axis, affording the octahedral iridium(III) dihydride structures $a$ and b, respectively (see Scheme II). In the present case, isomer $b$ is unlikely on steric grounds, and although this type of dihydrogen addition is often under kinetic control, ${ }^{3 b, 8}$ here it must be guided by thermodynamic factors.

For complexes 4,5 , and 9 dihydrogen can also add to the T-shaped three-coordinate conformation. Oxidative addition to such a species will normally be directed (on steric grounds) such that a diatomic substrate approaches the metal center oriented perpendicular to the coordination plane with its midpoint in this plane to afford a five-coordinate complex (Scheme II, right). ${ }^{12}$ In accordance with the observed product formation, the two hydrides then remain mutually cis, since upon subsequent intramolecular coordination of the tertiary amine group the octahedral cis-dihydride complexes 10,11 , and 15 are generated.
However, without further information it is impossible to say by which of the two mechanisms outlined here the fluxional iridium(I) complexes 4,5 , and 9 react with dihydrogen.

Reactions of $\operatorname{Ir}^{\mathrm{I}}\left[\mathrm{C}_{6} \mathrm{H}_{2}\left(\mathrm{CH}_{2} \mathrm{NMe}_{2}\right)-2-\mathrm{R}^{1}-4-\mathrm{R}^{2}-6\right]$ (COD) (4-9) with Dihydrogen at Other Temperatures. In contrast to the behavior of the iridium(I) complexes 4-9 with dihydrogen at $-20^{\circ} \mathrm{C}$, at temperatures below ca. -40 ${ }^{\circ} \mathrm{C}$ no measurable reaction was observed, despite the presumed enhanced thermodynamic preference for dihydride formation. This is in accord with theoretical calculations by Saillard and Hoffmann. ${ }^{13}$ They state that side-on dihydrogen additions to planar $\mathrm{d}^{8}-\mathrm{ML}_{4}$ complexes proceed better if two trans ligands can bend toward each other (in the $y z$ plane). This destabilizes the $\mathrm{d}_{y z}$ orbital, which can than provide an improved overlap with the dihydrogen $\sigma^{*}$ orbital. This situation can only be reached if these complexes exhibit sufficient thermal motion. This temperature-dependent behavior of the iridium(I) complexes 4-9 toward dihydrogen points to the conclusion that a slight bending in these square-planar metal $\mathrm{d}^{8}$ complexes is indeed required to induce a side-on addition of dihydrogen.

The reaction of the iridium(I) complexes 4-9 with dihydrogen, when carried out at room temperature, led to gradual decomposition and formation of 1-( $\left(\mathrm{Me}_{2} \mathrm{NCH}_{2}\right)-3-$ $\mathrm{R}^{1}-5-\mathrm{R}^{2}-\mathrm{C}_{6} \mathrm{H}_{3}$, cyclooctane, and probably metallic iridium. The kinetic barriers are now low enough at this temperature for hydrogenation of the double bonds of COD.

Finally in this section, it is worth noting that the analogous rhodium(I) complexes 1-3 also exhibit a temperature-dependent behavior toward molecular hydrogen. However, they differ from the iridium(I) complexes in that there was no intermediate temperature range in which rhodium(III) dihydride species could be detected. ${ }^{5}$

Thermally Induced Reactions of $\operatorname{Ir}^{\mathrm{III}} \mathrm{H}_{2}\left[\mathrm{C}_{6} \mathrm{H}_{2}\right.$ $\left.\left(\mathrm{CH}_{2} \mathrm{NMe}_{2}\right)-2-\mathrm{R}^{1}-4-\mathrm{R}^{2}-6\right](\mathrm{COD})$ (10-15). Solutions of the iridium(III) dihydride complexes 10-15, prepared from 4-9 in situ in $\mathrm{CD}_{2} \mathrm{Cl}_{2}$ at $-20^{\circ} \mathrm{C}$, undergo various reactions on warming to $+20^{\circ} \mathrm{C}$. These reactions were monitored by ${ }^{1} \mathrm{H} \mathrm{NMR}$, and in all cases the resonances assigned to $\mathrm{Ir}^{\mathrm{III}} \mathrm{H}_{2}\left[\mathrm{C}_{6} \mathrm{H}_{2}\left(\mathrm{CH}_{2} \mathrm{NMe}_{2}\right)-2-\mathrm{R}^{1}-4-\mathrm{R}^{2}-6\right](\mathrm{COD})$ disappear above $0^{\circ} \mathrm{C}$. The types of reaction that take place, summarized in Scheme III, are found to depend primarily on the bulkiness of the $R^{2}$ group of the aryl ligand. 

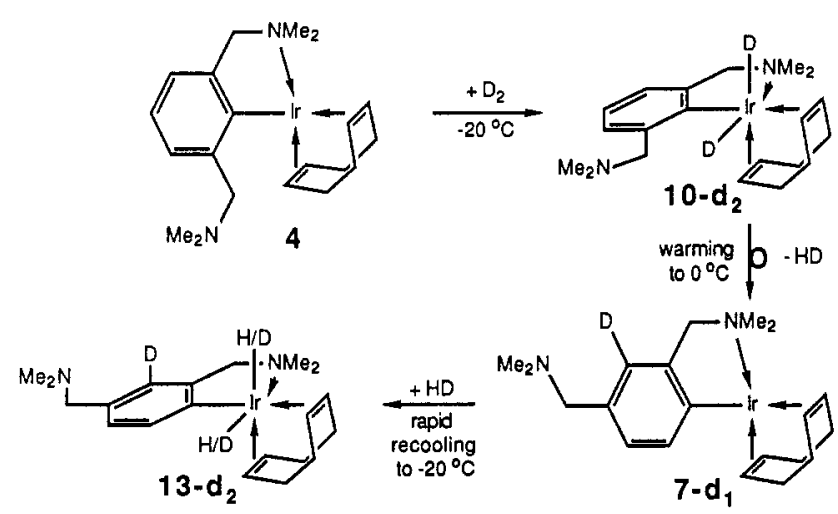

Figure 4. Reaction of $\operatorname{Ir}^{\mathrm{I}}\left[\mathrm{C}_{6} \mathrm{H}_{3}\left(\mathrm{CH}_{2} \mathrm{NMe}_{2}\right)_{2}-2,6\right](\mathrm{COD})$ (4) with $\mathrm{D}_{2}$.

Complexes 12-14, which all have a proton at the 6position of the aryl ligand $\left(R^{2}=H\right)$, lose dihydrogen quantitatively, re-forming their starting iridium(I) complexes 6-8, respectively. The reaction of 6-8 with dihydrogen to form the dihydrides $12-14$ is therefore reversible.

However, complexes 10,11 , and 15 , which all have an alkyl group as $\mathrm{R}^{2}$, do not give back their respective iridium(I) precursors on warming. Instead of $\operatorname{Ir}^{\mathrm{I}}\left[\mathrm{C}_{6} \mathrm{H}_{3^{-}}\right.$ $\left.\left(\mathrm{CH}_{2} \mathrm{NMe}_{2}\right)-2-\mathrm{R}-6\right](\mathrm{COD})\left[\mathrm{R}=\mathrm{CH}_{2} \mathrm{NMe}_{2}\right.$ (4), $\left.\mathrm{Me}(5)\right]$, the respective dihydrides 10 and 11 yield mainly the rearranged isomers $\operatorname{Ir}^{\mathrm{I}}\left[\mathrm{C}_{6} \mathrm{H}_{3}\left(\mathrm{CH}_{2} \mathrm{NMe}_{2}\right)-2-\mathrm{R}-4\right](\mathrm{COD})(7$ and 8) $(70 \%)$, accompanied by some decomposition to 1 $\left(\mathrm{Me}_{2} \mathrm{NCH}_{2}\right)-3-\mathrm{R}-\mathrm{C}_{6} \mathrm{H}_{4}$ and "IrH(COD)" (30\%). ${ }^{14}$ If a solution of $\mathrm{Ir}^{\mathrm{III}} \mathrm{H}_{2}\left[\mathrm{C}_{6} \mathrm{H}_{3}\left(\mathrm{CH}_{2} \mathrm{NMe}_{2}\right)_{2}-2,6\right]$ (COD) (10) (which itself does not react with $\mathrm{PPh}_{3}$ ) is warmed up in the presence of 2 equiv of $\mathrm{PPh}_{3}$, a $1: 1$ mixture of 1,3$\left(\mathrm{Me}_{2} \mathrm{NCH}_{2}\right)_{2} \mathrm{C}_{6} \mathrm{H}_{4}$ and the known ${ }^{17}$ complex IrH(COD)$\left(\mathrm{PPh}_{3}\right)_{2}$ is obtained, so corroborating the formation of a "IrH(COD)" moiety during the reaction. ${ }^{14}$ Complex 15 reacts on warming to afford only $1,3,5-\left(\mathrm{Me}_{2} \mathrm{NCH}_{2}\right)_{3} \mathrm{C}_{6} \mathrm{H}_{3}$ as the organic product.

In contrast to the $\mathrm{H}-\mathrm{H}$ elimination of the dihydride complexes $12-14$, the nature of the reaction products of the iridium(III) dihydrides 10,11 , and 15 points to $C$ (aryl)-H reductive elimination pathways. The 6-position alkyl groups in these latter complexes appear to exert a repulsive force on the neighboring hydride atom such that $\mathrm{C}$ (aryl)- $\mathrm{H}$ reductive elimination becomes more favorable than dihydrogen elimination.

For 10 and 11, the formation of the iridium(I) complexes 7 and 8 suggests a rearrangement process (see Scheme III) very similar to that found for the thermal conversion of complexes 4 and 5 to 7 and 8 at $60^{\circ} \mathrm{C}$ (see Scheme I). This latter process has been shown to be triggered by a $\mathrm{C}-\mathrm{H}$ addition of a MeN group to the iridium(I) center. ${ }^{6}$ In the former process, addition of $\mathrm{H}-\mathrm{H}$ initiates the intramolecular rearrangement, which now proceeds at a much lower temperature $\left(0^{\circ} \mathrm{C}\right)$, and therefore dihydrogen is actually acting as a catalyst.

The mechanism of the dihydrogen catalyzed $4 / 7$ and $5 / 8$ rearrangement was examined by following the reaction of $\operatorname{Ir}^{\mathrm{I}}\left[\mathrm{C}_{6} \mathrm{H}_{3}\left(\mathrm{CH}_{2} \mathrm{NMe}_{2}\right)_{2}-2,6\right](\mathrm{COD})$ (4) with dideuterium (see Figure 4). At $-20^{\circ} \mathrm{C}$ this yields, as anticipated, $\mathrm{Ir}^{\mathrm{III}} \mathrm{D}_{2}$ -

(14) Although hydride clusters such as $\mathrm{Rh}_{4} \mathrm{H}_{4}(\mathrm{COD})_{4}{ }^{15}$ and $\mathrm{Ir}_{4} \mathrm{H}_{4}$ $(\mathrm{COD})_{4}\left(\mathrm{C}_{3} \mathrm{H}_{4}\right)^{16}$ are known, no such species were observed by ${ }^{1} \mathrm{H}$ NMR during the present experiments.

(15) (a) Schmidt, G. F.; Muetterties, E. L.; Beno, M. A.; Williams, J. M. Proc. Natl. Acad. Sci. U.S.A. 1981, 78, 1318. (b) Kulzick, M.; Price, R. T.; Muetterties, E. L. Organometallics 1982, 1, 1256.

(16) Mueller, J.; Menig, H.; Pickardt, J. Angew. Chem. 1981, 93, 407.

(17) Shapley, J. R.; Osborn, J. A. J. Am. Chem. Soc. 1970, 92, 6976.

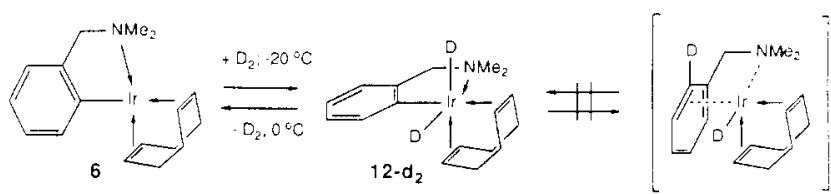

Figure 5. Reaction of $\operatorname{Ir}^{\mathrm{I}}\left[\mathrm{C}_{6} \mathrm{H}_{4}\left(\mathrm{CH}_{2} \mathrm{NMe}_{2}\right)-2\right](\mathrm{COD})(6)$ with $\mathrm{D}_{2}$.

$\left[\mathrm{C}_{6} \mathrm{H}_{3}\left(\mathrm{CH}_{2} \mathrm{NMe}_{2}\right)_{2}-2,6\right](\mathrm{COD})\left(10-d_{2}\right)$. When the mixture was warmed to $0^{\circ} \mathrm{C}, \operatorname{Ir}\left[\mathrm{C}_{6} \mathrm{H}_{2}\left(\mathrm{CH}_{2} \mathrm{NMe}_{2}\right)_{2}-2,4-\mathrm{D}-3\right]$ (COD) $\left(7-d_{1}\right)$ was formed exclusively. Although the concomitant formation of HD in this briefly warmed solution was not demonstrated directly, rapid recooling of the reaction mixture to $-20^{\circ} \mathrm{C}$ resulted in the formation of a species formulated as Ir III $\mathrm{HD}\left[\mathrm{C}_{6} \mathrm{H}_{2}\left(\mathrm{CH}_{2} \mathrm{NMe}_{2}\right)_{2}-2,4-\mathrm{D}-3\right]$ (COD) $\left(13-d_{2}\right)$. Its ${ }^{1} \mathrm{H}$ NMR spectrum has hydride signals at -9.2 and $-17.9 \mathrm{ppm}$, but with half the intensity found for fully protonated 13. [In principle this species could also be a $1 / 1$ molar mixture of the $\mathrm{H}_{2}\left(13-d_{1}\right)$ and $\mathrm{D}_{2}\left(13-d_{3}\right)$ complexes. However a dihydride complex $\left(13-d_{1}\right)$ cannot be formed because 4 , which is the only possible $H$ source for $\mathrm{H}_{2}$ in this rearrangement, has already been consumed (see the derived mechanism shown in Scheme III).] Presumably, this is a result of a random cis addition of the generated HD molecules to $7-d_{1}$.

The reaction of $\operatorname{Ir}^{\mathrm{I}}\left[\mathrm{C}_{6} \mathrm{H}_{4}\left(\mathrm{CH}_{2} \mathrm{NMe}_{2}\right)-2\right](\mathrm{COD})$ (6) with $\mathrm{D}_{2}$ at $-20^{\circ} \mathrm{C}$ in $\mathrm{CD}_{2} \mathrm{Cl}_{2}$ affords $\operatorname{Ir}^{\mathrm{III}} \mathrm{D}_{2}\left[\mathrm{C}_{6} \mathrm{H}_{4}\left(\mathrm{CH}_{2} \mathrm{NMe}_{2}\right)-\right.$ 2](COD) $\left(12-d_{2}\right)$ (see Figure 5). When this solution is warmed, the starting complex 6 is recovered with no deuterium incorporated into the 3-position of the aryl ring. This rules out the occurrence of reversible $\mathrm{C}(\operatorname{aryl})-\mathrm{H}$ elimination/addition reactions in the iridium(III) dihydride complex 12 , and therefore probably in 13 and 14 as well.

The mechanisms of the thermally induced and dihydrogen-catalyzed $4 / 7$ and $5 / 8$ isomerizations (shown in Schemes I and III, respectively) are very similar. They include the involvement of some well-defined intermediates, whose nature can be used to explain why the thermally induced isomerization is more effective than the dihydrogen-catalyzed one (which is accompanied by $30 \%$ decomposition). For the two processes, the initial activation of 4 and 5 involves oxidative addition of a $\mathrm{H}-\mathrm{H}$ and a C(alkyl)-H bond, respectively. Subsequent C(aryl)-H reductive elimination takes place affording two completely different intermediates, 16a and 17a. In intermediate 16a (Scheme I), the aryl ligand is bonded to the iridium(I) center by means of a Ir-C(alkyl) $\sigma$-bond, probably in combination with an arene $\pi$-bond. The presence of the $\sigma$-bond probably explains why the aryl ligand at this stadium does not dissociate from intermediate $16 a$ but instead exclusively adds intramolecularly another $\mathrm{C}$ (aryl)-H bond via 16b. However, in the other intermediate $17 \mathrm{a}$ (Scheme III) the aryl ligand, now present as neutral 1$\left(\mathrm{Me}_{2} \mathrm{NCH}_{2}\right)-3-\mathrm{R}-\mathrm{C}_{6} \mathrm{H}_{4}$, is bonded to the iridium center only by weak Ir-N and/or $\pi$-arene interactions. It is likely that at this point the observed $30 \%$ decomposition to the free arene $1-\left(\mathrm{Me}_{2} \mathrm{NCH}_{2}\right)-3-\mathrm{R}-\mathrm{C}_{6} \mathrm{H}_{4}$ and "IrH(COD)" occurs. ${ }^{14}$ The weak linkage of the arene ligand in intermediate 17a is demonstrated when $\mathrm{PPh}_{3}$ is present in solution during warmup. This increases the decomposition pathway from 30 to $100 \%$, as $\mathrm{PPh}_{3}$ fully substitutes the arene ligand from intermediate $17 \mathbf{a}$, thereby forming $\operatorname{IrH}(\mathrm{COD})\left(\mathrm{PPh}_{3}\right)_{2}$. Normally however, in the dominant process $(70 \%)$ intermediate $17 \mathrm{a}$ rearranges to its conformational isomer $17 \mathrm{~b}$, whereupon the arene ligand "re-metalates" at the, less sterically hindered, former 3-position of the aryl ligand. This affords the rearranged iridium(III) dihydrides 13 and 14 (which were not actually observed by ${ }^{1} \mathrm{H}$ NMR during 
this conversion), from which subsequent $\mathrm{H}_{2}$ elimination affords the more stable iridium(I) complexes 7 and 8 (Scheme III).

The thermal reaction of $\operatorname{Ir}^{I I I} \mathrm{H}_{2}\left[\mathrm{C}_{6} \mathrm{H}_{2}\left(\mathrm{CH}_{2} \mathrm{NMe}_{2}\right)_{3}\right.$ $2,4,6]$ (COD) (15), which also proceeds via $\mathrm{C}$ (aryl)- $\mathrm{H}$ reductive elimination, affords the intermediate IrH(COD) [1,3,5-( $\left.\left.\mathrm{Me}_{2} \mathrm{NCH}_{2}\right)_{3} \mathrm{C}_{6} \mathrm{H}_{3}\right]$ (cf. 17a/b). All three aryl $\mathrm{C}-\mathrm{H}$ bonds are now equivalent and equally unfavorable for "re-metalation" due to the steric hindrance of the three bulky $\mathrm{CH}_{2} \mathrm{NMe}_{2}$ groups. Since "re-metalation" would only result in re-formation of the iridium(III) dihydride complex 15 (a reaction that is obviously thermodynamically unfavorable), the alternative pathway followed is dissociation of the neutral arene ligand 1,3,5-( $\left(\mathrm{Me}_{2} \mathrm{NCH}_{2}\right)_{3} \mathrm{C}_{6} \mathrm{H}_{3}$ from the metal center.

\section{Conclusions}

Iridium(I) complexes of type $\operatorname{Ir}^{\mathrm{I}}\left[\mathrm{C}_{6} \mathrm{H}_{2}\left(\mathrm{CH}_{2} \mathrm{NMe}_{2}\right)-2\right.$ -

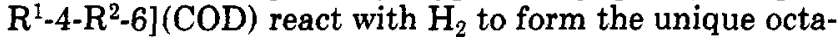

hedral iridium(III) dihydrides $\mathrm{Ir}^{\mathrm{III}} \mathrm{H}_{2}\left[\mathrm{C}_{6} \mathrm{H}_{2}\left(\mathrm{CH}_{2} \mathrm{NMe}_{2}\right)\right.$-2$\left.\mathrm{R}^{1}-4-\mathrm{R}^{2}-6\right](\mathrm{COD})$, which display interesting reactivity patterns. From these reactions it can be concluded that, without altering the innermost ligand sphere of the metal center, intramolecular steric effects can drastically change the direction of $\mathrm{H}-\mathrm{H}$ and $\mathrm{C}-\mathrm{H}$ bond elimination/addition reactions in iridium(III) compounds. Whereas $\mathrm{Ir}^{\mathrm{III}} \mathrm{H}_{2-}$ $\left[\mathrm{C}_{6} \mathrm{H}_{2}\left(\mathrm{CH}_{2} \mathrm{NMe}_{2}\right)-2-\mathrm{R}^{1}-4-\mathrm{R}^{2}-6\right](\mathrm{COD})$ complexes that have a proton as the $\mathrm{R}^{2}$ group react further by simple $\mathrm{H}-\mathrm{H}$ elimination, those where $R^{2}$ is a bulkier alkyl group react further by an exclusive $\mathrm{C}(\operatorname{aryl})-\mathrm{H}$ reductive elimination process. Therefore, when discussing the electronic and thermodynamic factors of $\mathrm{H}-\mathrm{H}$ and $\mathrm{C}-\mathrm{H}$ bond activation, it is also important to take possible interligand repulsions into account.

Acknowledgment. Richard A. Nordemann and Miss Jacqueline M. A. Wouters are thanked for practical assistance. Professor K. Vrieze is thanked for helpful discussions.

\title{
Electronic Structure of Triple-Decker Sandwich Compounds with $P_{5}, P_{6}, A_{5}$, and $C_{n} H_{n}$ as Middle Rings ${ }^{\dagger}$
}

\author{
Eluvathingal D. Jemmis* and A. Chandrasekhar Reddy \\ School of Chemistry, University of Hyderabad, Central University P.O., Hyderabad-500 134, India
}

Received December 3, 1987

\begin{abstract}
Extended Hückel calculations on $\mathrm{CpNiCpNiCp}+, \mathrm{CpCoC}_{6} \mathrm{H}_{6} \mathrm{CoCp}, \mathrm{CpCoC}_{7} \mathrm{H}_{7} \mathrm{CoCp}, \mathrm{CpVC}_{6} \mathrm{H}_{6} \mathrm{VCp}$, $\mathrm{C}_{6} \mathrm{H}_{6} \mathrm{CrC}_{6} \mathrm{H}_{6} \mathrm{CrC}_{6} \mathrm{H}_{6}, \mathrm{CpMoP}_{6} \mathrm{MoCp}, \mathrm{CpCrP} \mathrm{P}_{5} \mathrm{CrCp}$, and $\mathrm{CpMoAs}_{5} \mathrm{MoCp}\left(\mathrm{Cp}=\eta^{5}-\mathrm{C}_{5} \mathrm{H}_{5}\right)$ have been carried out to find the relationship of the stability of the metal-ring combination with the number of valene electrons. The electron count varies from 34 electrons to 26 electrons depending on the magnitude of the interactions $4 \mathrm{a}-\mathrm{e}$. With the vanadium complex the $\mathrm{e}_{2}{ }^{\prime \prime}$ interaction, $4 \mathrm{~b}$, is substantial. With $\mathrm{P}_{6}, \mathrm{P}_{5}$ and As $\mathrm{s}_{5}$ ligands, the $\mathrm{a}_{2}$ " interaction, $4 \mathrm{e}$, also becomes very strong. CpMoAs${ }_{5} \mathrm{MoCp}$ leads to a degenerate HOMO with three electrons leading to a distortion of the $\mathrm{As}_{5}$ ring, with two long and three short As-As bonds. The isoelectronic $P_{5}$ compound does not have such a distortion as the HOMO is a nondegenerate MO with only one electron.
\end{abstract}

Triple-decker sandwiches, 1 , are formally obtained from metallocenes, 2 , by the additional sandwiching with a metal and a ring. The following metal and ring combinations are known among them: metal $=\mathrm{V}, \mathrm{Cr}, \mathrm{Fe}, \mathrm{Co}, \mathrm{Ni}, \mathrm{Mo}, \mathrm{Pt}$; terminal ring $=\mathrm{C}_{5} \mathrm{H}_{5}, \mathrm{C}_{6} \mathrm{H}_{6}, \mathrm{C}_{2} \mathrm{~B}_{2} \mathrm{SH}_{4}, \mathrm{C}_{3} \mathrm{~B}_{2} \mathrm{H}_{5}$; middle ring $=\mathrm{C}_{5} \mathrm{H}_{5}, \mathrm{C}_{6} \mathrm{H}_{6}, \mathrm{P}_{5}, \mathrm{As}_{5}, \mathrm{P}_{6}, \mathrm{C}_{2} \mathrm{~B}_{2} \mathrm{SH}_{4}, \mathrm{C}_{4} \mathrm{~B}_{2} \mathrm{H}_{5}, \mathrm{C}_{3} \mathrm{~B}_{2} \mathrm{H}_{5}{ }^{1-16}$ Table I lists these complexes with the number of valence electrons and the $\mathbf{M}-\mathbf{M}$ distances wherever known. There are many interesting structural variations in these compounds. The $\mathrm{M}-\mathrm{M}$ distance falls within the bonding range only with phosphorus and arsenic rings in the middle..$^{14-16}$ While most of the triple-decker sandwich compounds with $\mathrm{C}_{n} H_{n}, \mathrm{P}_{5}$, and $\mathrm{P}_{6}$ as middle rings retain local $\mathrm{C}_{n}$ axis, the $\mathrm{As}_{5}$ ring in $\mathrm{CpMoAs}{ }_{5} \mathrm{MoCp}$ has a distorted geometry with two As-As bonds longer than the other three. ${ }^{16}$ The structure appears as a combination of $\mathrm{As}_{3}$ and $\mathrm{As}_{2}$ as in 3. The middle As in the $\mathrm{As}_{3}$ group is farthest from the metals so that an $\eta^{4}$-description is often used for the $\mathrm{As}_{5}$ ligand.

The number of electrons around the metals also varies considerably. If only the $\pi$-electrons of the ligands are included in the electron count, there are 26 electrons in the vanadium complex $\mathrm{C}_{5} \mathrm{H}_{5} \mathrm{VC}_{6} \mathrm{H}_{6} \mathrm{VC}_{5} \mathrm{H}_{5}$ and 34 electrons in the nickel complex $\mathrm{C}_{5} \mathrm{H}_{5} \mathrm{NiC}_{5} \mathrm{H}_{5} \mathrm{NiC}_{5} \mathrm{H}_{5}^{+}$. There are any

${ }^{\dagger}$ Dedicated to Professors P. T. Narasimhan and M. V. George, I. I. T. Kanpur, on their sixtieth birthdays.
Table I. Currently Known Triple-Decker Sandwich Compound with Metal-Metal Distances, Number of Valence Electrons, and References

\begin{tabular}{|c|c|c|c|}
\hline compound & $\begin{array}{c}\text { M-M } \\
\text { dist }^{a}\end{array}$ & $\begin{array}{c}\text { no. of } \\
\text { valence } \\
\text { electrons }\end{array}$ & ref \\
\hline (1) $\mathrm{CpNiCpNiCp}^{+}$ & 3.580 & 34 & 1 \\
\hline (2) $\mathrm{CpCoC}_{6} \mathrm{R}_{6} \mathrm{CoCp}$ & & 34 & 3 \\
\hline (3) $\mathrm{CpVC}_{6} \mathrm{R}_{6} \vee \mathrm{Cp}$ & 3.400 & 26 & 2 \\
\hline (4) $\mathrm{C}_{6} \mathrm{H}_{6} \mathrm{CrC}_{6} \mathrm{H}_{6} \mathrm{CrC}_{6} \mathrm{H}_{6}$ & 3.338 & 30 & 4 \\
\hline (5) $\mathrm{CpFe}\left(\mathrm{C}_{2} \mathrm{~B}_{2} \mathrm{SR}_{4}\right) \mathrm{FeCp}$ & 3.236 & 30 & 6 \\
\hline $\begin{array}{l}\text { (6) }\left(\mathrm{C}_{2} \mathrm{~B}_{2} \mathrm{SR}_{4}\right) \mathrm{Co}_{2}\left(\mathrm{C}_{2} \mathrm{~B}_{2} \mathrm{SR}_{4}\right) \mathrm{Co}\left(\mathrm{C}_{2} \mathrm{~B}_{2} \mathrm{SR}_{4}\right) \\
\text { (7) } \mathrm{CpM}\left(\mathrm{C}_{3} \mathrm{~B}_{2} \mathrm{R}_{6}\right) \mathrm{M}^{\prime} \mathrm{Cp}\end{array}$ & & 30 & 7 \\
\hline (a) $\mathbf{M}=\mathrm{Ni}, \mathbf{M}^{\prime}=\mathrm{Ni}$ & 3.416 & 33 & 8 \\
\hline (b) $\mathrm{M}=\mathrm{Fe}, \mathrm{M}^{\prime}=\mathrm{Co}$ & 3.337 & 32 & 8 \\
\hline (c) $\mathrm{M}=\mathrm{Fe}, \mathrm{M}^{\prime}=\mathrm{Co}_{0}$ & 3.204 & 30 & 8 \\
\hline (d) $\mathrm{M}=\mathrm{Co}, \mathrm{M}^{\prime}=\mathrm{Co}$ & & 31 & 8 \\
\hline (8) $\mathrm{CpCo}\left(\mathrm{C}_{3} \mathrm{~B}_{2} \mathrm{R}_{5}\right) \mathrm{CoCp}$ & 3.140 & 30 & 9 \\
\hline (9) $\mathrm{CpRh}\left(\mathrm{C}_{4} \mathrm{~B}_{2} \mathrm{R}_{6}\right) \mathrm{RhCp}^{2+}$ & 3.440 & 30 & 10 \\
\hline (a) $\mathrm{M}=\mathrm{Co}, \mathrm{M}^{\prime}=\mathrm{Pt}$ & & 30 & 11 \\
\hline (b) $\mathrm{M}=\mathrm{Ni}, \mathrm{M}^{\prime}=\mathrm{Pt}$ & & 31 & 11 \\
\hline (c) $\mathrm{M}=\mathrm{Co}, \mathrm{M}^{\prime}=\mathrm{Ni}$ & & 30 & 11 \\
\hline (11) $\left(\mathrm{C}_{6} \mathrm{H}_{5} \mathrm{R}\right) \mathrm{Fe}\left(\mathrm{C}_{3} \mathrm{~B}_{2} \mathrm{H}_{5}\right) \mathrm{Ni}\left(\mathrm{C}_{3} \mathrm{~B}_{2} \mathrm{H}_{5}\right)$ & & 30 & 12 \\
\hline (12) $\mathrm{CpMoP}_{6} \mathrm{MoCp}$ & 2.648 & 28 & 14 \\
\hline (13) $\mathrm{CpMoAs}_{5} \mathrm{MoCp}$ & 2.762 & 27 & 16 \\
\hline (14) $\mathrm{CpCrP}_{5} \mathrm{CrCp}$ & 2.728 & 27 & 15 \\
\hline
\end{tabular}

${ }^{\circ}$ Distances in $\AA$.

number of complexes with intermediate electron counts of 28 and 30 (Table I). Several theoretical studies have 